\title{
Comparative evaluation of the calculated norms of mineral fertilizers interaction effectiveness with various bioagents and adaptogenic preparations on crops cruciferous oilseeds
}

\author{
Faik N. Safiollin ${ }^{1, *}$, Rustam M. Nizamov ${ }^{1}$, Michael V. Panasyuk ${ }^{2}$, Salavat R. Suleymanov ${ }^{1}$, and Ayrat A. Akhmetzyanov ${ }^{1}$ \\ ${ }^{1}$ Kazan State Agrarian University, Kazan 420015, Republic of Tatarstan, Russia \\ ${ }^{2}$ Kazan (Volga) Federal University, Kazan 420008, Republic of Tatarstan, Russia
}

\begin{abstract}
Studies conducted as part of the Federal target program "Research and Development in Priority Directions for the Development of the Russian Science and Technology Complex for 2014-2020", showed high efficiency of interaction of calculated norms of mineral fertilizers with modern bioagents RECB-50B, RECB-95B and adaptogenic drugs. At the same time, the actual yield of spring rapeseed of the Gedemin variety exceeds the planned one ( $3 \mathrm{t} / \mathrm{ha}$ ) by $9.3-12.3 \%$, respectively, the chemical load on the environment is reduced and the cost of production of oilseeds is reduced.
\end{abstract}

\section{Introduction}

The increase in the production of oilseeds due to the cultivation of spring rape, white mustard, etc., most adapted to the soil and climatic conditions of the Republic of Tatarstan, in modern conditions should be solved by the use of biological products that are environmentally and economically feasible and justify the work of farmers. Among these priorities, of course, is the implementation of a comprehensive program for the development of biotechnology, approved by the President of our country V.V. Putin on April 24, 2012. It is aimed at reducing costs in the production of competitive, environmentally friendly food products based on the widespread use of fertilizer-stimulating compounds, modern organic mineral nutrient solutions containing easily digestible amino acids, chelated forms of micronutrient fertilizers and biological preparations.

In this regard, the issues of the interaction of the calculated norms of mineral fertilizers with biological active substances in the technology of cultivating cruciferous oil crops, which are considered in this work, are not only relevant, but also significant from both theoretical and practical points of view.

\section{Research Program and Methodology}

The studies were conducted on the experimental field of the Chistopol State Plot of the Republic of Tatarstan. Location of the plot: latitude - 55.3768737233; Longitude -50.7433859300 .

The humus content was $5 \%$ (according to Tyurin), mobile phosphorus 250 and exchange potassium $147 \mathrm{mg} / \mathrm{kg}$ of soil (according to Chirikov). The soil of the experimental plot was characterized by a low boron content (0.17-0.19), medium - copper (2.8-3.8), and higher than average molybdenum $(0.20-0.29 \mathrm{mg} / \mathrm{kg}$ of soil). The amount of absorbed bases was at the level of 34.9-35.2 mg/equiv. Per $100 \mathrm{~g}$ of soil, the degree of saturation with bases is $83-85 \%$, the lowest moisture capacity is $28-30 \%$, the density of soil compaction is $1.18-1.21 \mathrm{~g} / \mathrm{cm}^{3}$, the content of water-resistant aggregates from 0.10 to $0.25 \mathrm{~mm}$ in size ranged from 44.8 to $45.1 \%$. The $\mathrm{pH}$ of the salt extract is 6.4-6.5.

Consequently, the agrochemical characteristic of the soil of the experimental plot corresponds to typical leached chernozems, which occupy $39 \%$ of the arable land of our republic.

The precursor of the research object was pure steam. In the experiment, a cultivar of spring rape of the Belorussian selection Gedemin was cultivated. Mineral fertilizers were applied as a general background before sowing with the expectation of a planned yield of $3.0 \mathrm{t} / \mathrm{ha}$ of oilseeds of the studied crop. The repetition of the experiment is fourfold, the plot area is $32 \mathrm{~m}^{2}$.

The following microorganism strains were used in the studies:

- RECB-95 B (Bacillus subtilis);

- RECB-50 B (Bacillus spp.).

Seed treatment with the bioagents was carried out on the day of sowing, and foliar top dressing was performed in the phase of 3-4 pairs of real spring rape leaves.

An extract from millet sprouts was used as an adaptogen. The studies were carried out with financial support from the Ministry of Education and Science of the Russian Federation in the framework of the Federal Target Program "Research and Development in Priority Directions for the Development of the Russian Science and Technology Complex for 2014-2020", agreement number 14.610.21.0017, and a unique project identification number is RFMEFI61017X0017.

* Corresponding author: faik1948@mail.ru 
Field experiments were carried out in accordance with the methods described in the works of V.F. Moiseichenko [1] and V.M. Lukomets [2]. Statistical processing of research results was carried out by the method of variance analysis [3].

\section{Results}

Among the microorganisms used to protect plants, an important place is occupied by bacteria from the genus
Bacillus, which were included in the composition of the studied bioagents. They, according to RI Safina [4], T.V. Zharekhina [5], R.M. Nizamova [6] exhibit antagonistic activity against a significant number of plant pathogens. Bacillus bacteria also positively affect the immunity of agricultural crops $[7,8]$. In addition, the symbiosis between plants and microorganisms (plants provide them with carbohydrates) is clearly manifested in the field germination of spring rape seeds $[9,10]$ (Table 1).

Table 1. The effect of bioagents and adaptogens on field germination of spring rape

\begin{tabular}{|c|c|c|c|c|}
\hline \multirow{2}{*}{ Experience option } & \multicolumn{2}{|c|}{ Field germination, $\mathrm{pcs} / \mathrm{m}^{2}$} & \multicolumn{2}{|c|}{ Increase } \\
\hline & $\mathrm{pcs} / \mathrm{m}^{2}$ & $\%$ & $\mathrm{pcs} / \mathrm{m}^{2}$ & $\%$ \\
\hline The control & 140 & 56 & - & - \\
\hline Kruiser, 15.0 1/t (seed treatment) & 168 & 67 & 28 & 20.0 \\
\hline $\begin{array}{l}\text { Risoplan, } 1.0 \text { 1/t (seed treatment) + Risoplan, } \\
1.01 / \text { ha (spraying of plants) }\end{array}$ & 170 & 68 & 30 & 21.4 \\
\hline $\begin{array}{l}\text { RECB-95 B, } 2.0 \text { l/t (seed treatment) + RECB- } \\
95 \mathrm{~B}, 1.0 \mathrm{l} / \mathrm{t} \text { (spraying plants) }\end{array}$ & 170 & 68 & 30 & 21.4 \\
\hline $\begin{array}{l}\text { RECB-50 B, } 2.01 / \mathrm{t} \text { (seed treatment) + RECB- } \\
50 \mathrm{~B}, 1.0 \mathrm{l} / \mathrm{t} \text { (spraying plants) }\end{array}$ & 173 & 69 & 33 & 23.6 \\
\hline $\begin{array}{l}\text { RECB-95 B, } 2.01 / \mathrm{t}+\text { adaptogen, } 1.01 / \mathrm{t} \text { (seed } \\
\text { treatment) + RECB-95 B, } 1.01 / \mathrm{t}+\text { adaptogen, } \\
1.01 / \text { ha (spraying plants) }\end{array}$ & 178 & 71 & 38 & 27.1 \\
\hline $\begin{array}{l}\text { RECB-50 B, } 2.01 / \mathrm{t}+\text { adaptogen, } 1.01 / \mathrm{t} \text { (seed } \\
\text { treatment) + RECB-50 B, } 1.01 / \mathrm{t}+\text { adaptogen, } \\
1.01 / \text { ha (spraying plants) }\end{array}$ & 180 & 72 & 40 & 28.6 \\
\hline $\begin{array}{l}\text { Kruiser, } 15.0 \mathrm{l} / \mathrm{t} \text { (seed treatment) + RECB-95 B, } \\
1.0 \mathrm{l} / \mathrm{t} \text { (spraying of plants) }\end{array}$ & 175 & 70 & 45 & 25.0 \\
\hline $\begin{array}{l}\text { Kruiser, } 15.0 \mathrm{l} / \mathrm{t} \text { (seed treatment) + RECB-50 B, } \\
1.01 / \mathrm{t} \text { (spraying plants) }\end{array}$ & 175 & 70 & 45 & 25.0 \\
\hline $\mathrm{LSD}_{05}$ & 12,1 & & & \\
\hline
\end{tabular}

So, in the control variant of the experiment, 140 out of 250 sown seeds emerged (56\% field germination). Under the same conditions, under the influence of presowing treatment of seeds with the studied drugs, the field germination of the object of study increased to 170-180 $\mathrm{pcs} / \mathrm{m}^{2}$. At the same time, the RECB-50 V + adaptogen variant with $72 \%$ field germination was distinguished. In this experiment, the field germination rate of spring rape is increased by $28.6 \%$ compared with the control. Such a sharp increase in field germination of this crop is apparently because the supply of nutrients in the seeds provides shoots from the soil depth of $2-3 \mathrm{~cm}$. In this regard, without additional nutrients that are present in bioagents in easily digestible form to the seeds, once in a depth of more than $3 \mathrm{~cm}$, there is simply not enough energy to germinate to the surface.

This explains the low field germination of the studied crop (from 56 to $72 \%$ ) compared with spring crops (82-85\%), since the adopted technology for pre-sowing cultivation of soil and modern seeders do not provide a uniform incorporation of small seeds of spring rape for optical shallow depth.

The intensity of dense stem formation depends not only on field germination, but also to a greater extent on the sprouts growth rate. The sprouts growth power is a quick transition of plants to autotrophic nutrition. It is determined by the dry mass of the studied culture in the phase of 2 pairs of true leaves of tenfold repetition (table. 2).
As the research results show, in addition to field germination, presowing treatment of seeds with the studied bioagents and adaptogenic preparations has a great influence on the sprouts growth rate. In this regard, a comparative evaluation of Risoplan, RECB-95 V and RECB-50 V shows the advantage of RECB-50 V + adaptogen. At the same time, the dry mass of spring rape in the phase of 2 pairs of true leaves increased to $0.22 \mathrm{~g} /$ plant versus $0.16 \mathrm{~g} / \mathrm{plant}$ in the control $(38 \%$ higher than the control).

When analyzing the plant growth power, it turned out that the value of adaptogen is also significant. So, the difference between the analyzed value between the control and seed treatment with the bioagents RECB-95 $\mathrm{V}$ and RECB-50 V was only $0.01 \mathrm{~g} /$ plant, while the addition of the adaptogen to the same working solution at the rate of $1 \mathrm{l} / \mathrm{t}$ of seeds ensured an increase of 0.04 and $0.06 \mathrm{~g} /$ plant, respectively.

There is a direct correlation between the plant growth power and the formation of the root system of spring rape, the faster the plants switch to autotrophic nutrition, the higher the intensity of growth and development of the root system (Table 3).

Spring rape sowing was carried out in the first decade of May, May 16 - the date of the appearance of the first sprouts, after 25 days the budding phase began and after another 20 days - the flowering phase. The last phase of development is the ripening of seeds 1.5-2.0 months after flowering. 
Table 2. The growth rate of sprouts of spring rape, depending on the method of seedbed preparation

\begin{tabular}{|c|c|c|c|}
\hline \multirow{2}{*}{ Experience option } & \multirow{2}{*}{$\begin{array}{l}\text { The sprouts growth rate } \\
\text { g/plant in the phase of } 2 \\
\text { pairs of true leaves }\end{array}$} & \multicolumn{2}{|c|}{ Increase } \\
\hline & & $\mathrm{g} /$ solution & $\%$ \\
\hline The control & 0.16 & - & - \\
\hline Kruiser, 15.0 1/t (seed treatment) & 0.17 & 0.01 & 6 \\
\hline Risoplan, 1.0 1/t (seed treatment) + Risoplan, 1.0 1/ha (spraying of plants) & 0.17 & 0.01 & 6 \\
\hline RECB-95 B, 2.0 1/t (seed treatment) + RECB-95 B, 1.0 l/t (spraying plants) & 0.18 & 0.02 & 13 \\
\hline RECB-50 B, 2.0 1/t (seed treatment) + RECB-50 B, 1.0 l/t (spraying plants) & 0.18 & 0.02 & 13 \\
\hline $\begin{array}{l}\text { RECB-95 V, } 2.01 / \mathrm{t}+\text { adaptogen, } 1.0 \mathrm{l} / \mathrm{t} \text { (seed treatment) + RECB-95 V, } 1.0 \\
1 / \mathrm{t}+\text { adaptogen, } 1.0 \mathrm{l} / \mathrm{ha} \text { (spraying plants) }\end{array}$ & 0.20 & 0.04 & 25 \\
\hline $\begin{array}{l}\text { RECB-50 V, } 2.01 / \mathrm{t}+\text { adaptogen, } 1.0 \mathrm{l} / \mathrm{t} \text { (seed treatment) + RECB-50 V, } 1.0 \\
1 / \mathrm{t}+\text { adaptogen, } 1.0 \mathrm{l} / \mathrm{ha} \text { (spraying plants) }\end{array}$ & 0.22 & 0.06 & 38 \\
\hline Kruiser, $15.0 \mathrm{l} / \mathrm{t}$ (seed treatment) + RECB-95 V, $1.0 \mathrm{l} / \mathrm{t}$ (spraying of plants) & 0.19 & 0.03 & 19 \\
\hline Kruiser, $15.0 \mathrm{l} / \mathrm{t}$ (seed treatment) + RECB-50 V, $1.0 \mathrm{l} / \mathrm{t}$ (spraying plants) & 0.19 & 0.03 & 19 \\
\hline
\end{tabular}

Table 3. The effect of bioagents and adaptogenic preparations on the growth and development of the root system of spring rape (active soil layer, $\mathrm{cm}$ )

\begin{tabular}{|c|c|c|c|c|}
\hline Experience option & $\begin{array}{c}\text { Sowing - } \\
\text { sprouts }\end{array}$ & $\begin{array}{l}\text { Sprouts - } \\
\text { budding }\end{array}$ & $\begin{array}{l}\text { Budding - } \\
\text { Flowering }\end{array}$ & $\begin{array}{l}\text { Flowering - } \\
\text { ripening }\end{array}$ \\
\hline The control & 5.3 & 20.3 & 23.8 & 24.6 \\
\hline Kruiser, 15.0 l/t (seed treatment) & 5.6 & 21.8 & 24.1 & 25.0 \\
\hline Risoplan, 1.0 1/t (seed treatment) + Risoplan, 1.0 1/ha (spraying plants) & 5.7 & 22.1 & 24.6 & 25.4 \\
\hline RECB-95 V, $2.01 / \mathrm{t}$ (seed treatment) + RECB-95 V, $1.0 \mathrm{l} / \mathrm{t}$ (spraying plants) & 6.0 & 22.7 & 24.9 & 26.1 \\
\hline RECB-50 V, $2.0 \mathrm{l} / \mathrm{t}$ (seed treatment) + RECB-50 V, $1.0 \mathrm{l} / \mathrm{t}$ (spraying plants) & 6.1 & 22.9 & 25.0 & 26.6 \\
\hline $\begin{array}{c}\text { RECB-95 V, } 2.0 \mathrm{l} / \mathrm{t}+\text { adaptogen, } 1.0 \mathrm{l} / \mathrm{t} \text { (seed treatment) + RECB-95 V, } 1.0 \\
\text { 1/t + adaptogen, } 1.0 \mathrm{l} / \mathrm{ha} \text { (spraying plants) }\end{array}$ & 6.8 & 24.4 & 26.6 & 27.0 \\
\hline $\begin{array}{c}\text { RECB-50 V, } 2.0 \mathrm{l} / \mathrm{t}+\text { adaptogen, } 1.0 \mathrm{l} / \mathrm{t} \text { (seed treatment) + RECB-50 V, } 1.0 \\
\text { l/t + adaptogen, } 1.01 / \text { ha (spraying plants) }\end{array}$ & 7.2 & 25.1 & 27.8 & 28.2 \\
\hline Kruiser, 15.0 1/t (seed treatment) + RECB-95 V, 1.0 1/t (spraying plants) & 6.2 & 24.7 & 26.4 & 27.0 \\
\hline Kruiser, 15.0 1/t (seed treatment) + RECB-50 V, 1.0 1/t (spraying plants) & 6.4 & 24.8 & 26.7 & 27.2 \\
\hline
\end{tabular}

In each development phase, the depth of the active soil layer (the soil layer in which the bulk of the roots are located) was determined. During the measurements, it was revealed that the root system of spring rape in the initial stage develops extremely slowly. In the "sowingsprouts" phase, roots occupy from 5.3 in the control, up to $7.8 \mathrm{~cm}$ of the soil layer in the variant with seed treatment RECB-50 B + adaptogen.

More intensive root growth occurs during the budding and flowering phases of spring rape. Without presowing seed treatment, the increase is $15-18.5 \mathrm{~cm}$, and in the variants using bioagents and adaptogens in 2 doses, the active soil layer increases to $26.6-27.8 \mathrm{~cm}$. Moreover, the individual roots of spring rape penetrate to a depth of more than $100 \mathrm{~cm}$, extracting additional nutrients and moisture.

The accelerated transition of plants to autotrophic nutrition of a large number of sprouts obtained, the formation of a deeply penetrating root system due to presowing seed treatment and additional non-root top dressing with biological preparations contributed to the formation of up to $42-48$ thousand $\mathrm{m}^{2} /$ ha of leaf rape spring rape plants with a height of $117-125 \mathrm{~cm}$.

As a result, spring rape fruit elements, depending on the studied methods of using biologics, differed both from control (without presowing seed treatment) and traditional seed inlay (Kruizer $151 / \mathrm{t}$ ) according to the following features (Table 4):

- the number of productive pods increased from $30 \mathrm{pcs} /$ plant in the control to 40 on the variant RECB-50
$\mathrm{V}(2.0 \mathrm{l} / \mathrm{t}$ of seeds $)+$ adaptogen $(1.0 \mathrm{l} / \mathrm{t})+\mathrm{RECB}-50 \mathrm{~V}$ (1.0 1/ha);

- the number of seeds in the pod in this experiment exceeded the control by $23 \%$;

- the density of the grass stand before harvesting reached a maximum value of $152 \mathrm{pcs} / \mathrm{m}^{2}$;

- the mass of 1000 seeds were $3.22 \mathrm{~g}$ against 3.15 in the control;

- biological yield from the use of RECB-50 V in two doses (pre-sowing treatment in combination with an adaptogen and foliar application) exceeded the control by $86 \%$ (5.20 against $2.8 \mathrm{t} / \mathrm{ha}$ in the control).

Before proceeding with the analysis of the gross yield of rapeseed oilseeds (actual yield), three factors should be noted:

- firstly, in May 2019, precipitation fell $86 \%$ more than the average long-term indicators. During the formation of pods (July), the moisture supply was within normal limits (95 mm), and during oilseed loading a record amount of precipitation fell (103\% higher than normal);

- secondly, the average daily air temperature in July and August was 1 ниже lower, which became the main factor in restraining the growth of many pests of spring rape.

And, finally, the formation of a dense tall agrocenosis contributed to the displacement of weeds from the herbage.

As a result of the merger of the above 3 favorable factors, it led to the formation of yields of oilseeds of spring rape higher than planned (Table 5). 
Table 4. Structure and biological productivity of spring rape

\begin{tabular}{|c|c|c|c|c|c|}
\hline Experience option & $\begin{array}{l}\text { Number of } \\
\text { products } \\
\text { pods, } \\
\text { pcslsol }\end{array}$ & $\begin{array}{c}\text { The number } \\
\text { of seeds in the } \\
\text { pod, pcs. }\end{array}$ & $\begin{array}{c}\text { Number of } \\
\text { plants before } \\
\text { harvesting, } \\
\text { pcs } / \mathrm{m}^{2}\end{array}$ & $\begin{array}{l}\text { The mass } \\
\text { of } 1000 \\
\text { seeds, } g\end{array}$ & $\begin{array}{c}\text { Biological } \\
\text { productivity, } \\
\text { t/ha }\end{array}$ \\
\hline The control & 30 & 22 & 129 & 3.15 & 2.80 \\
\hline Kruiser, 15.0 l/t (seed treatment) & 30 & 23 & 135 & 3.18 & 2.96 \\
\hline $\begin{array}{l}\text { Risoplan, } 1.0 \text { 1/t (seed treatment) + Risoplan, } 1.0 \text { l/ha } \\
\text { (spraying plants) }\end{array}$ & 31 & 23 & 136 & 3.18 & 3.01 \\
\hline $\begin{array}{l}\text { RECB-95 V, } 2.01 / \mathrm{t} \text { (seed treatment) + RECB-95 V, } 1.01 / \mathrm{t} \\
\text { (spraying plants) }\end{array}$ & 33 & 24 & 149 & 3.20 & 3.77 \\
\hline $\begin{array}{l}\text { RECB-50 V, } 2.01 / \mathrm{t} \text { (seed treatment) + RECB-50 V, } 1.01 / \mathrm{t} \\
\text { (spraying plants) }\end{array}$ & 34 & 24 & 158 & 3.20 & 4.12 \\
\hline $\begin{array}{l}\text { RECB-95 V, } 2.0 \mathrm{l} / \mathrm{t}+\text { adaptogen, } 1.0 \mathrm{l} / \mathrm{t} \text { (seed treatment) }+ \\
\text { RECB-95 V, } 1.0 \mathrm{l} / \mathrm{t}+\text { adaptogen, } 1.0 \mathrm{l} / \mathrm{ha} \text { (spraying plants) }\end{array}$ & 38 & 26 & 151 & 3.21 & 4.78 \\
\hline $\begin{array}{l}\text { RECB-50 V, } 2.0 \mathrm{l} / \mathrm{t}+\text { adaptogen, } 1.0 \mathrm{l} / \mathrm{t} \text { (seed treatment) + } \\
\text { RECB-50 V, } 1.0 \mathrm{l} / \mathrm{t}+\text { adaptogen, } 1.0 \mathrm{l} / \mathrm{ha} \text { (spraying plants) }\end{array}$ & 40 & 27 & 150 & 3.21 & 5.20 \\
\hline $\begin{array}{l}\text { Kruiser, } 15.0 \mathrm{l} / \mathrm{t} \text { (seed treatment) + RECB-95 V, } 1.0 \mathrm{l} / \mathrm{t} \\
\text { (spraying plants) }\end{array}$ & 34 & 25 & 150 & 3.19 & 4.06 \\
\hline $\begin{array}{l}\text { Kruiser, } 15.01 / \mathrm{t} \text { (seed treatment) + RECB-50 V, } 1.0 \mathrm{l} / \mathrm{t} \\
\text { (spraying plants) }\end{array}$ & 34 & 25 & 150 & 3.20 & 4.24 \\
\hline
\end{tabular}

Table 5. The effectiveness of the use of bioagents and adaptogenic drugs in crops of spring rape

\begin{tabular}{|c|c|c|c|}
\hline \multirow{2}{*}{ Experience option } & \multirow{2}{*}{$\begin{array}{l}\text { Actual oilseed } \\
\text { productivity, } \mathrm{t} / \mathrm{ha}\end{array}$} & \multicolumn{2}{|c|}{ Increase } \\
\hline & & t/ha & $\%$ \\
\hline The control & 2.24 & - & - \\
\hline Kruiser, 15.0 l/t (seed treatment) & 2.40 & 0.16 & 7.1 \\
\hline Risoplan, 1.0 1/t (seed treatment) + Risoplan, 1.0 1/ha (spraying plants) & 2.46 & 0.22 & 9.8 \\
\hline RECB-95 V, $2.01 / \mathrm{t}$ (seed treatment) + RECB-95 V, 1.0 1/t (spraying plants) & 2.82 & 0.58 & 25.9 \\
\hline RECB-50 V, 2.0 1/t (seed treatment) + RECB-50 V, 1.0 1/t (spraying plants) & 3.15 & 0.91 & 40.6 \\
\hline $\begin{array}{l}\text { RECB-95 V, } 2.0 \mathrm{l} / \mathrm{t}+\text { adaptogen, } 1.0 \mathrm{l} / \mathrm{t} \text { (seed treatment) + RECB-95 V, } 1.0 \mathrm{l} / \mathrm{t}+ \\
\text { adaptogen, } 1.0 \mathrm{l} / \mathrm{ha} \text { (spraying plants) }\end{array}$ & 3.28 & 1.04 & 46.4 \\
\hline $\begin{array}{l}\text { RECB-50 V, } 2.0 \mathrm{l} / \mathrm{t}+\text { adaptogen, } 1.0 \mathrm{l} / \mathrm{t} \text { (seed treatment) + RECB-50 V, } 1.0 \mathrm{l} / \mathrm{t}+ \\
\text { adaptogen, } 1.0 \mathrm{l} / \mathrm{ha} \text { (spraying plants) }\end{array}$ & 3.37 & 1.13 & 50.4 \\
\hline Kruiser, 15.0 l/t (seed treatment) + RECB-95 V, 1.0 l/t (spraying plants) & 3.06 & 0.82 & 36.6 \\
\hline Kruiser, 15.0 l/t (seed treatment) + RECB-50 V, 1.0 1/t (spraying plants) & 3.19 & 0.96 & 42.4 \\
\hline LSD05 & 0.16 & & \\
\hline
\end{tabular}

Table 6. Economic efficiency of the interaction of calculated norms of mineral fertilizers with bioagents from the RECB group and adaptogenic preparations in the production of rapeseed oilseeds

\begin{tabular}{|l|c|c|c|c|c|}
\hline \multicolumn{1}{|c|}{ Experience option } & $\begin{array}{c}\text { The cost of } \\
\text { gross output, } \\
\text { thousand } \\
\text { rubles/ha }\end{array}$ & $\begin{array}{c}\text { Total costs, } \\
\text { thousand } \\
\text { rubles/ha }\end{array}$ & $\begin{array}{c}\text { Net profit, } \\
\text { thousand } \\
\text { rubles/ha }\end{array}$ & $\begin{array}{c}\text { Profitability, } \\
\%\end{array}$ & $\begin{array}{c}\text { Cost of 1-ton } \\
\text { oilseeds, } \\
\text { thousand } \\
\text { rubles }\end{array}$ \\
\hline The control & 44.8 & 31.6 & 13.2 & 41.8 & 14.1 \\
\hline Kruiser, 15.0 l/t (seed treatment) & 48.0 & 33.2 & 14.8 & 44.5 & 13.8 \\
\hline $\begin{array}{l}\text { Risoplan, 1.0 l/t (seed treatment) + Risoplan, } \\
1.0 \text { l/ha (spraying plants) }\end{array}$ & 49.2 & 33.9 & 15.3 & 45.1 & 13.8 \\
\hline $\begin{array}{l}\text { RECB-95 V, 2.0 l/t (seed treatment) + RECB-95 } \\
\text { V, 1.0 l/t (spraying plants) }\end{array}$ & 56.4 & 38.1 & 18.3 & 46.8 & 13.5 \\
\hline $\begin{array}{l}\text { RECB-50 V, 2.0 l/t (seed treatment) + RECB-50 } \\
\text { V, 1.0 l/t (spraying plants) }\end{array}$ & 63.0 & 40.3 & 22.7 & 56.3 & 12.8 \\
\hline $\begin{array}{l}\text { RECB-95 V, 2.0 l/t + adaptogen, 1.0 l/t (seed } \\
\text { treatment) + RECB-95 V, 1.0 l/t + adaptogen, } \\
1.0 \text { l/ha (spraying plants) }\end{array}$ & 65.6 & 40.5 & 25.1 & 62.0 & 12.3 \\
\hline $\begin{array}{l}\text { RECB-50 V, 2.0 l/t + adaptogen, 1.0 l/t (seed } \\
\text { treatment) + RECB-50 V, 1.0 l/t + adaptogen, } \\
1.0 \text { l/ha (spraying plants) }\end{array}$ & 67.4 & 41.0 & 26.4 & 64.4 & 12.2 \\
\hline $\begin{array}{l}\text { Kruiser, 15.0 l/t (seed treatment) + RECB-95 V, } \\
1.0 \text { l/t (spraying plants) }\end{array}$ & 61.2 & 39.7 & 21.5 & 54.2 & 13.0 \\
\hline $\begin{array}{l}\text { Kruiser, 15.0 l/t (seed treatment) + RECB-50 V, } \\
1.0 \text { l/t (spraying plants) }\end{array}$ & 63.8 & 40.1 & 23.7 & 59.1 & 12.6 \\
\hline
\end{tabular}


So, pre-sowing seed treatment with RECB-50 V + working solution adaptogen and foliar application with the same preparations provided the yield of spring rape $3.37 \mathrm{t} / \mathrm{ha}$, which is 12.3 percent higher than the estimated yield. The yield increase to the control experiment was $1.13 \mathrm{t} / \mathrm{ha}(50.4 \%)$.

At the same time, a significant decrease in the effectiveness of the classic seed dresser of Kruizer cruciferous oilseeds should be emphasized, which is associated with an increase in the resistance of cruciferous fleas, cabbage moths, rapeseed beetle, stalked secretive hunter, cruciferous sawfly and many others. etc.

It is precisely for this reason that the efficiency of pre-sowing seed treatment by Kruiser at the rate of $15 \mathrm{l} / \mathrm{t}$ of seeds in relation to the control is only $7.1 \%$ versus $36.6-42.4 \%$ with the addition of RECB-95 V or RECB$50 \mathrm{~V}$.

Reducing the costs of protecting plants from diseases and pests, increasing the efficiency of applying the calculated norms of mineral fertilizers undoubtedly had a great influence on the economic indicators of the production of rapeseed oilseeds (Table 6).

Of particular note is the high profitability of the production of rapeseed oilseeds in the soil-climatic conditions of the Republic of Tatarstan (from 41.8 to $64.4 \%$ ), which is associated with the price of its sale (20 thousand rubles/t) against 8-10 thousand rubles/tons of spring wheat grain).

Even under such favorable conditions for cultivating this crop, the difference in net profit from using RECB $50 \mathrm{~V}$ in combination with the adaptogen in two doses increases to 26.4 thousand rubles/ha against 14.8 thousand rubles/ha Kruiser seed treatment at the rate of $151 / \mathrm{t}$ (78.4\% increase).

However, the difference in the cost of production of 1 ton of oilseed between the above compared options is reduced and amounts to only $15.6 \%$, which is associated with the costs of cleaning, transportation, sorting and drying of additional crops.

Nevertheless, from the sale of each ton of products to the cash register of the economy, from 5.9 to 7.8 thousand rubles of cash.

\section{Conclusion}

In order to reduce the chemical load on the environment, save money, fully realize the potential possibility of calculated norms of mineral fertilizers on leached chernozems of the Republic of Tatarstan in order to obtain 3.28-3.37 t/ha of oilseeds of spring rape, it is recommended to pre-sow seeds with strains of RECB-50 $\mathrm{V}(2.01 / \mathrm{t})$ or RECB-95 V $(2.0 \mathrm{l} / \mathrm{t})$ in combination with leaf dressing in the phase of 3-4 pairs of real leaves with the same strains (norm $1.0 \mathrm{l} / \mathrm{ha}$ consumption) with the addition of an adaptogenic preparation .

\section{References}

1. V.F. Moiseichenko et al., Fundamentals of scientific research in agronomy (Kolos, Moscow, 1996)

2. V.M. Lukomets, N.M. Tishkov, V.F. Rams, Methodology for conducting field agrotechnical experiments with oilseeds (Krasnodar, 2010)

3. B.A. Armor, The technique of field experience (Agropromizdat, Moscow, 1985)

4. R.I. Safin, L.Z. Karimova, Sh.Z. Validov, Material of the Int. Forum "Biotechnology: Status and Development Prospects”, 33-35 (2018)

5. T.V. Zharyokhin, Achievem. of sci. and technol. of the agro-industr. complex, 11, 46-48 (2018)

6. R.M. Nizamov, F.N. Safiollin, M.M. Khismatullin, M.I. Giliazov, F.A. Davletov, R.S. Shakirov, Int. J. of Advanc. Biotechnol. and Res., 10(1), 341-347 (2019)

7. M. Halpern, U. Yermiyahu, A. Bar-Tal, M. Ofek, D. Minz, T. Muller, Advanc. in Agron., 130, 141$174(2015)$

8. A.K. Srivastava, P. Suprasanna, R. Pasala, P.S. Minhas, Advanc. in Agron., 137, 237-278 (2016)

9. J.R. Reeve, L.A. Hoagland, J.J. Villalba, P.M. Carr, A. Atucha, C. Cambardella, D.R. Davis, K. Delate, Advanc. in Agron., 137, 319-367 (2016)

10. S. Goltsman, T.V. Gorbacheva, N.A. Rendov, Bull. of the Omsk State Agrar. Univer., 1(17), 12-14 (2015) 